\title{
Research on the Intergenerational Flow of Migrant Workers' Education
}

\author{
DU XING-YAN ${ }^{1,2}$, LI ZHONG-BIN*1
}

\author{
1.School of Management, Fujian Agriculture and Forestry University, Fuzhou, Fujian 350002, China; \\ 2.School of Management, Fujian University of Technology, Fuzhou, Fujian 350118, CHINA
}

\begin{abstract}
Migrant workers are an important part of China's labor market, accounting for one fifth of China's total population. However, the living conditions of this huge group still need to be improved. After 40 years, why does this group still have the situation of frequent job mobility, low employment level and low social status? In essence, education is the key element, and the intergenerational flow of education makes this key role continue. The empirical results show that: the intergenerational flow of education does exist in migrant workers. The education level of fathers has a significant impact on the education of children at the level of $1 \%$, while the education level of mothers has the same trend, and there are subtle gender differences in the intergenerational impact on children's education. Therefore, we should pay close attention to the education intergenerational flow phenomenon of migrant workers, to better promote their development and enhance their welfare.
\end{abstract}

Key words: migrant workers; education; intergenerational flow; Occupational Mobility

Received: April 2, 2020. Revised: August 11, 2020. Accepted: August 19, 2020. Published: August 27, 2020.

\section{Introduction}

According to the difference of long-term residence, individual household registration is divided into urban household registration and rural household registration. The so-called migrant workers refer to those whose household registration is still in rural areas and who have been engaged in non-agricultural industries or have been working outside for 6 months or more. It mainly refers to the population flow among provinces in China. Generally speaking, these workers flow from underdeveloped areas to economically developed areas in order to seek better economic sources.

Migrant workers account for a large proportion in the overall number of China's labor market. According to the National Bureau of statistics, the total population of Chinese mainland was 1400.05 million, with 290.77 million of migrant workers at the end of 2019. That is to say, the migrant workers group accounts for one fifth of the total population in China. Migrant workers not only have a large number of people, but also maintain a growing trend in the last five years (as shown in Figure 1) .The career development and welfare improvement of this group is one of the important connotations of improving the quality of national life. However, the living conditions of this huge group still need to be improved. After 40 years, why does this group still have the situation of frequent job mobility, low employment level and low social status. What factors lead to the difficulties in their life and career choice?

Shao Yihang and Zhang Chaoyang believe that relational social capital contributes to the upward mobility of the whole society. Ji believes that China's unique household registration system and India's unique caste system make the labor market fragmented and intergenerational mobility hindered. However, Guo Congbin's research shows that intergenerational occupation and industry inheritance result in occupational segmentation and industry segmentation of labor market, and this intergenerational effect will gradually weaken with the development of regional economy, and education 
investment is an effective way to improve the intergenerational effect of workers. We also believe that the human capital formed by taking education investment as the main way is the most important factor affecting intergenerational mobility. In fact, education has been the subject of much attention in both academic and practical fields. In the 1960s, American sociologists P. M. Blau and O. D. Duncan began to pay attention to the mechanism of education in intergenerational mobility. According to the theory of human capital, investment in education, health and migration can increase personal human capital, labor productivity and personal income, which is conducive to improving the compound interest effect of social members. As the most important role in human capital investment, education plays a particularly important role. It is easy to think that it may be the problem of educational opportunities for this group, so the state has also given great attention to the nine-year compulsory education for the children of migrant workers. But there are still some problems and difficulties in reality. Therefore, this paper holds that it is not only a simple problem of children's education, but also a problem of intergenerational inheritance of migrant workers' education. There is an ancient Chinese saying "like father, like son". The society has been exploring the problem of "learning the second generation". Does this phenomenon also exist in migrant workers? Is it necessary to start from this root to completely improve the living conditions and social welfare of migrant workers?

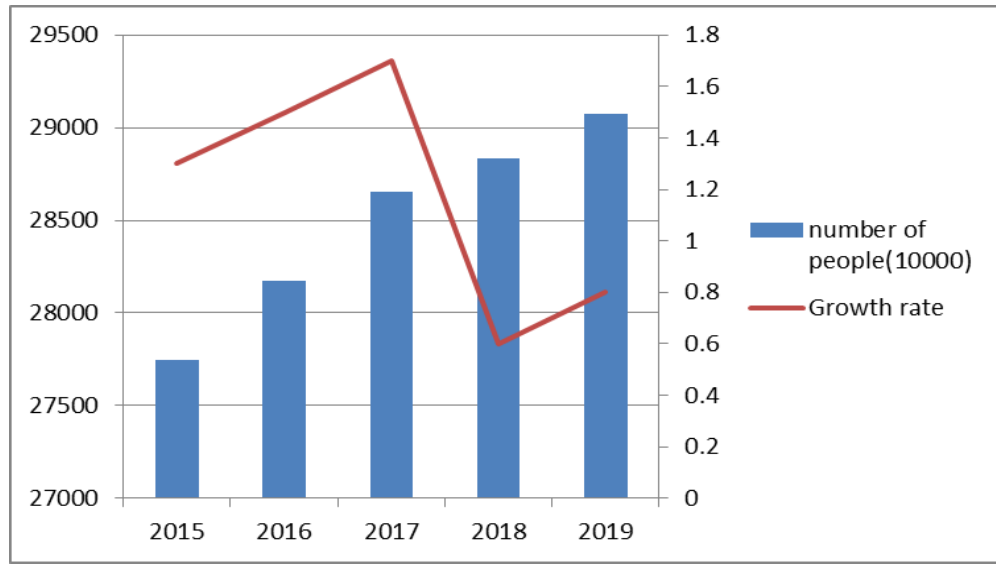

Figure 1: Growth trend of migrant workers in the recent five years

(Data from the National Bureau of statistics)

\section{Analyses on the Current Situation of}

\section{Migrant Workers' Occupational}

\section{Mobility}

The origin of migrant workers is in line with China's economic and social development, mainly experienced four development waves: the first is in the $1980 \mathrm{~s}$, with the emergence of township enterprises, the majority of farmers "leave the land do not leave their hometown, enter the factory on the spot"; the second is in the 1990s, the migrant workers "leave the land and the countryside, enter the city and enter the factory", this group explores into a broader urban space; the third is that after the 21 st century, migrant workers have accelerated the large-scale cross provincial flow, with the proportion of migrant workers in 2001 reaching 44\%; the fourth is after the 18th National Congress of the Communist Party of China, migrant workers have entered a new stage of citizenization of "upgrading skills and integrating into the city".

The number of migrant workers is huge, and the occupation flow is quite frequent. In 2019, the total number of migrant workers has reached 290.77 million, an increase of 2.41 million over the previous year, an increase of $0.8 \%$. Among them, there were 116.52 million local migrant workers, an increase of 
820000 over the previous year, an increase of $0.7 \%$; 174.25 million migrant workers, an increase of 1.59 million over the previous year, an increase of $0.9 \%$. Among the migrant workers, there were 135 million migrant workers living in cities and towns at the end of the year, which was basically the same as that of the previous year. According to the statistical data in 2020, among the migrant workers, 99.17 million migrant workers were employed in the province, an increase of 2.45 million over the previous year, an increase of $2.5 \%$; and a cross provincial migrant workers of 75.08 million, a decrease of 860000 over the previous year, a decrease of $1.1 \%$. The employment of migrant workers in the province accounted for $56.9 \%$ of migrant workers out of the province, an increase of $0.9 \%$ over the previous year. In terms of regions, except for the proportion of migrant workers employed in Northeast China to migrant workers decreased by 3.4 percentage points over the previous year, the proportion of migrant workers employed in eastern, central and western provinces increased by $0.1,1.4$ and 1.2 percentage points respectively over the previous year. As shown in Table 1.

Migrant workers in China are a very special group, a large number of groups, is an important part of the labor market. However, due to a variety of reasons, they are generally low in education, lack of relative skills in work types and frequent job rotation. Studies have shown that, job mobility among cities and inside the cities also has a significant negative effect on the employment quality, the index of employment quality of workers changing job inside city is 4.76 lower than that of the unconverted, while the index of employment quality of workers changing job among cities is 6.65 lower than that of the unconverted. It has been more than 40 years before and after these four waves. What causes generations of migrant workers to repeat the same fate? Some scholars believe that there are many factors that affect the process of migrant workers' citizenization. Education is an important factor for the new generation of migrant workers to obtain the ability of complete citizenization. Therefore, the key factor in promoting the citizenization of migrant workers and improving their happiness lies in education, which has been paid attention to by the current academic circles. However, this paper attempts to excavate the deep-seated reasons of migrant workers' education and analyze this problem from the education level of their parents.

Table 1: Regional distribution and composition of migrant workers in 2019

(Unit: ten thousand,\%)

\begin{tabular}{|c|c|c|c|c|c|c|}
\hline \multirow{3}{*}{$\begin{array}{c}\text { By output } \\
\text { location }\end{array}$} & \multicolumn{3}{|c|}{ Total amount of migrant workers } & \multicolumn{3}{|c|}{ Composition of migrant workers } \\
\hline & \multirow[t]{2}{*}{$\begin{array}{l}\text { Migrant } \\
\text { workers }\end{array}$} & & & \multirow[t]{2}{*}{$\begin{array}{l}\text { Migrant } \\
\text { workers }\end{array}$} & & \\
\hline & & $\begin{array}{c}\text { Trans } \\
\text { provincial } \\
\text { mobility }\end{array}$ & $\begin{array}{c}\text { Intra } \\
\text { provincial } \\
\text { mobility }\end{array}$ & & $\begin{array}{c}\text { Trans } \\
\text { provincial } \\
\text { mobility }\end{array}$ & $\begin{array}{c}\text { Intra } \\
\text { provincial } \\
\text { mobility }\end{array}$ \\
\hline Total & 17425 & 7508 & 9917 & 100.0 & 43.1 & 56.9 \\
\hline $\begin{array}{l}\text { Eastern } \\
\text { Region }\end{array}$ & 4792 & 821 & 3971 & 100.0 & 17.1 & 82.9 \\
\hline $\begin{array}{l}\text { Central } \\
\text { region }\end{array}$ & 6427 & 3802 & 2625 & 100.0 & 59.2 & 40.8 \\
\hline $\begin{array}{l}\text { Western } \\
\text { Region }\end{array}$ & 5555 & 2691 & 2864 & 100.0 & 48.4 & 51.6 \\
\hline $\begin{array}{c}\text { Northeast } \\
\text { China }\end{array}$ & 651 & 194 & 457 & 100.0 & 29.8 & 70.2 \\
\hline
\end{tabular}




\section{Theoretical Analyses on the}

\section{Intergenerational Flow of Migrant Workers' Education}

Scholars have never stopped exploring the intergenerational mobility of education, and have produced many research findings. Tom et al. conducted a study on the educational mobility of 46 countries in the world, and found the regional differences in educational intergenerational mobility were very large. Among them, the highest intergenerational elasticity of education was 0.6 in Latin America, the second was the United States and Western Europe, and the lowest was in Nordic countries. Doom et A1. analyzed the intergenerational transmission of education in 28 European countries. The analysis shows the education mobility in developing countries is significantly lower than that in industrial developed countries, and the intergenerational transmission of education in rapidly industrialized countries is significantly higher than that in countries with slow industrialization. Fessler et al. concluded the intergenerational elasticity of education in Austria was higher than that of the Netherlands, Finland, Sweden and other northern European countries, and closer to Italy, Slovenia and other southern European countries; the intergenerational elasticity of education gradually decreased over time, and the influence of the father's education level on the education level of children was higher than that of the mother's. There are many dimensions in the analysis of educational intergeneration in China. Ma Xiang analyzed the ethnic differences in the intergenerational transmission of education. Sun Yongqiang and Yan Yan analyzed the urban-rural differences of intergenerational education transmission. Zhao Hongxia and Gao Yongchao analyzed the intergenerational flow of education and its influencing factors from the perspective of educational equity. Wei Xiaoyan selected CFPS data, adopting OLS and the sub sample regression method. This paper examines the intergenerational transmission of higher education in China and its influencing factors. Zhu Jian and Li Xiaofei also conducted in-depth analysis on the urban-rural differences of education intergenerational transmission; Du Fenglian analyzed the scale of education intergenerational transmission and its influencing factors with the 2013 data of China's Health and Pension follow-up survey.

The above analysis shows the intergenerational transmission of education occurs in various countries, and the elasticity of intergenerational mobility in each country differs according to the varying national conditions. This paper attempts to introduce intergenerational education into the migrant workers group, which accounts for one fifth of the population, to discover the rules of the intergenerational flow of education in China. We hope to pay attention to this problem from the root, and then fundamentally improve the living conditions of migrant workers.

The author believes there is a close relationship between the education of migrant workers and the education of their parents, which is mainly realized in two ways. The first is the input of economic resources. According to the correlation between education level and income, it can be concluded most people with a higher education level will have more economic resources, and then they are more likely to invest in and directly affect their children's education. The second is the investment in non-economic resources, which may include social capital, psychological capital and so on. For example, parents with a higher education level may have more social capital to give their children, which will bring better educational choices; or they may also be influenced by their own educational ideas.

Specifically speaking, the intergenerational transmission of education between parents and children of migrant workers reflects the following three effects: first, income effect. There has been a consensus on the rate of return on education in the academic community. Psacharopoulos found that: from the perspective of Mincer's return on education, the world average was $9.7 \%$, the OECD average was $7.5 \%$, and the Asian average was $9.9 \%$. Deng Feng 
and Ding Xiaohao estimated that the rate of return on education in China is about $10 \%-11 \%$. Therefore, the more educated parents have better income, they will have more money to invest in their children's education, which will lead to the higher education level of their children; second, the demonstration effect. Parents with higher education level will imperceptibly pass on their successful experience to their children in family education, thus enhancing their children's competitiveness and thus enhancing their competitiveness. Third, the effect of resource accumulation. Wang Jing, a scholar, thinks that the level of education is an important condition that restricts the new generation of migrant workers to move to the occupation with high return rate of education. That is, the higher the education level of the parents, the more career opportunities and the more network resources they may have, which will affect the educational level of their children. At the same time, three references are added.

\section{Empirical Analysis on the} Intergenerational Flow of Migrant Workers' Education

\subsection{Descriptive analysis}

To verify the intergenerational mobility of migrant workers' education, the empirical data of this paper comes from the 2014 China labor force dynamic survey (CLDS) of Sun Yat-Sen University. The survey covers 29 provinces and cities in China, and all the subjects are in the labor force in sample families (family members aged 15-64 years). According to the previous model setting and research needs, the following variables are selected:

First, the education of the migrant workers themselves is taken as the dependent variable, which is measured by the education level and sorted using the highest educational background of the CLDS database. Second, the key explanatory variable is the educational status of their father's generation, which is mainly sorted by the father's educational background in the CLDS database. Third, the control variable indicates each person's education may be
To sum up, we can make the following assumptions:

Hypothesis: The higher the education level of the parents of migrant workers, the higher the education level of their children.

This can be expressed by the following formula: $\mathrm{Yi}=\mathrm{a}+\beta \mathrm{Xi}+\gamma \mathrm{Mi}+\varepsilon$

where Yi represents the education status of the i-th migrant workers, Xi represents the education of the migrant workers' parents, MI represents the control variable, $\alpha$ represents the constant term, $\beta$ represents the regression coefficient between independent variable $\mathrm{X}$ and dependent variable $\mathrm{Y}, \gamma$ is the regression coefficient of control variable $M$ and dependent variable $\mathrm{Y}$, and $\varepsilon$ stands for the random error term.

directly affected by his or her own related characteristic variables, so the migrant workers' education as well as gender, marriage, party membership, professional qualification certificate, working years, social network and health status are the control variables. According to the needs of the study, the database was screened for variables, and null and abnormal values were deleted. Finally, 3719 samples were obtained. The sample description statistics are shown in Table 2.

According to the statistical data, the average education level of the offspring is 8.52 years if the father's education level is less than 6 years, and the average education level of the offspring is 10.50 years if the father's education level is more than 7 years. At the same time, parents with different education levels have great differences in the number of children's migration, which may also be related to the education level of their children. In fact, this means that the higher the education level of parents is, the higher the education level of children is, which simply reflects the intergenerational inheritance of education. 
Table2: Descriptive Analysis of Variables

\begin{tabular}{llllll}
\hline Variable & Obs & Mean & Std. Dev. & Min & Max \\
edu_f & 3719 & 5.907233 & 3.959144 & 0 & 22 \\
sex & 3719 & .5557946 & .496944 & 0 & 1 \\
mar & 3719 & .802904 & .3978589 & 0 & 1 \\
par & 3574 & .0587577 & .2352035 & 0 & 1 \\
qua & 3718 & .1455083 & .3526601 & 0 & 1 \\
time & 1610 & 16.33168 & 10.82366 & 0 & 55 \\
soci & 3656 & 12.47812 & 29.01483 & 0 & 500 \\
health & 3719 & .6926593 & .4614538 & 0 & 1 \\
edu & 3706 & 9.220183 & 3.299136 & 0 & 16 \\
\hline
\end{tabular}

\subsection{Results analysis}

In order to test the intergenerational transfer of parents' education level to their children's education level, taking the education level of the children of migrant workers as the dependent variable, the father's education level as the independent variable, and the related characteristics of children as the control variable, the results shown in Table 3 are obtained by OLS regression. The results show the father's education significantly affects the children's education at the $1 \%$ level, that is, every year the father's education increases, the children's education increases by 0.15 years. This result shows the father's education years significantly affect the intergenerational transmission of migrant workers' children.

Table 3: Empirical results of intergenerational transmission of Education

\begin{tabular}{|c|c|c|c|c|c|c|c|c|}
\hline VARIAB & (1) & (2) & (3) & (4) & (5) & (6) & (7) & (8) \\
\hline LES & edu & edu & edu & edu & edu & edu & edu & edu \\
\hline \multirow[t]{2}{*}{ edu_f } & $0.295 * * *$ & $0.296 * * *$ & $0.269 * * *$ & $0.268 * * *$ & $0.167 * * *$ & $0.162 * * *$ & $0.150 * * *$ & $0.150 * * *$ \\
\hline & $(0.0128)$ & $(0.0128)$ & $(0.0127)$ & $(0.0128)$ & $(0.0189)$ & $(0.0191)$ & $(0.0182)$ & $(0.0182)$ \\
\hline \multirow[t]{2}{*}{ sex } & & $0.598 * * *$ & $0.535 * * *$ & $0.441 * * *$ & $0.305^{* *}$ & $0.280 * *$ & 0.128 & 0.121 \\
\hline & & $(0.102)$ & $(0.1000)$ & $(0.101)$ & $(0.137)$ & $(0.139)$ & $(0.133)$ & $(0.134)$ \\
\hline \multirow[t]{2}{*}{ mar } & & & $-1.461 * * *$ & $-1.482 * * *$ & $-0.547 * * *$ & $-0.636^{* * *}$ & $-0.544 * * *$ & $-0.541 * * *$ \\
\hline & & & $(0.127)$ & $(0.130)$ & $(0.195)$ & $(0.198)$ & $(0.189)$ & $(0.189)$ \\
\hline \multirow[t]{2}{*}{ par } & & & & $2.256^{* * *}$ & $1.793 * * *$ & $1.850 * * *$ & $1.445 * * *$ & $1.441 * * *$ \\
\hline & & & & $(0.215)$ & $(0.297)$ & $(0.303)$ & $(0.291)$ & $(0.291)$ \\
\hline \multirow[t]{2}{*}{ time } & & & & & $-0.0721 * * *$ & $-0.0694 * * *$ & $-0.0606^{* * *}$ & $-0.0602 * * *$ \\
\hline & & & & & $(0.00711)$ & $(0.00718)$ & $(0.00688)$ & $(0.00694)$ \\
\hline \multirow[t]{2}{*}{ soci } & & & & & & -0.00219 & -0.00166 & -0.00164 \\
\hline & & & & & & $(0.00241)$ & $(0.00229)$ & $(0.00229)$ \\
\hline \multirow[t]{2}{*}{ qua } & & & & & & & $2.087 * * *$ & $2.090 * * *$ \\
\hline & & & & & & & $(0.170)$ & $(0.170)$ \\
\hline \multirow[t]{2}{*}{ health } & & & & & & & & 0.0648 \\
\hline & & & & & & & & $(0.140)$ \\
\hline \multirow[t]{2}{*}{ Constant } & $7.477 * * *$ & $7.143 * * *$ & $8.508 * * *$ & $8.464 * * *$ & $9.840 * * *$ & $9.926 * * *$ & $9.496 * * *$ & $9.446 * * *$ \\
\hline & $(0.0910)$ & $(0.107)$ & $(0.159)$ & $(0.161)$ & $(0.252)$ & $(0.256)$ & $(0.246)$ & $(0.269)$ \\
\hline Observations & 3,706 & 3,706 & 3,706 & 3,562 & 1,546 & 1,505 & 1,505 & 1,505 \\
\hline R-squared & 0.125 & 0.134 & 0.163 & 0.188 & 0.200 & 0.197 & 0.270 & 0.270 \\
\hline
\end{tabular}

Standard errors in parentheses, ${ }^{* * *} \mathrm{p}<0.01,{ }^{* *} \mathrm{p}<0.05,{ }^{*} \mathrm{p}<0.1$ 


\subsection{Robustness test}

In order to test the stability of the father's generation to the intergenerational transfer of children's education, the mother's education level was selected for the robustness test. The results showed the mother's education also significantly affected the education of their offspring at the level of $1 \%$. Then the control variables are added gradually, showing the same trend. From the regression results in Table 4, the mother's education significantly affects the education of children at the level of $1 \%$, that is, every year of mother's education increases, the children's education increases by 0.16 years. This result shows the education level of mother has a significant effect on the intergenerational transmission of migrant workers' children; at the same time, it also shows that the influence of father's education on the education of their children is stable.

Table 4: Analysis of robustness test results of education intergenerational transmission

\begin{tabular}{|c|c|c|c|c|c|c|c|c|}
\hline VARIA & (1) & (2) & (3) & (4) & (5) & (6) & (7) & (8) \\
\hline BLES & edu & edu & edu & edu & edu & edu & edu & edu \\
\hline \multirow[t]{2}{*}{ edu_m } & $0.323 * * *$ & $0.326 * * *$ & $0.295 * * *$ & $0.302 * * *$ & $0.180 * * *$ & $0.178 * * *$ & $0.161 * * *$ & $0.161 * * *$ \\
\hline & $(0.0133)$ & $(0.0132)$ & $(0.0134)$ & $(0.0135)$ & $(0.0197)$ & (0.0198) & $(0.0190)$ & $(0.0190)$ \\
\hline \multirow[t]{2}{*}{ sex } & & $0.676 * * *$ & $0.611 * * *$ & $0.522 * * *$ & $0.363 * * *$ & $0.334 * *$ & 0.179 & 0.177 \\
\hline & & $(0.102)$ & $(0.101)$ & $(0.101)$ & $(0.138)$ & $(0.139)$ & $(0.133)$ & $(0.134)$ \\
\hline \multirow[t]{2}{*}{ mar } & & & $-1.297 * * *$ & $-1.299 * * *$ & $-0.494 * *$ & $-0.590 * * *$ & $-0.509 * * *$ & $-0.508 * * *$ \\
\hline & & & (0.129) & $(0.131)$ & $(0.195)$ & $(0.198)$ & $(0.189)$ & $(0.189)$ \\
\hline \multirow[t]{2}{*}{ par } & & & & 2. $372 * * *$ & 1. $892 * * *$ & 1. $912 * * *$ & $1.500 * * *$ & 1. $499 * * *$ \\
\hline & & & & $(0.215)$ & $(0.298)$ & $(0.304)$ & $(0.292)$ & $(0.292)$ \\
\hline \multirow[t]{2}{*}{ time } & & & & & $-0.067 * * *$ & $-0.064 * * *$ & $-0.056 * * *$ & $-0.056 * * *$ \\
\hline & & & & & $(0.00728)$ & (0.0073) & $(0.00702)$ & $(0.00706)$ \\
\hline \multirow[t]{2}{*}{ soci } & & & & & & -0.00195 & -0.00143 & -0.00142 \\
\hline & & & & & & (0.0024) & $(0.00229)$ & $(0.00230)$ \\
\hline \multirow[t]{2}{*}{ qua } & & & & & & & 2. $065 * * *$ & 2. $066 * * *$ \\
\hline & & & & & & & $(0.170)$ & $(0.170)$ \\
\hline \multirow[t]{2}{*}{ health } & & & & & & & & 0.0244 \\
\hline & & & & & & & & $(0.140)$ \\
\hline \multirow[t]{2}{*}{ Constant } & 7. $938 * * *$ & 7. $547 * * *$ & 8. $749 * * *$ & 8. $650 * * *$ & 9. $961 * * *$ & $10.02 * * *$ & 9. $613 * * *$ & 9. $596 * * *$ \\
\hline & $(0.0738)$ & $(0.0941)$ & $(0.151)$ & $(0.153)$ & $(0.240)$ & $(0.243)$ & $(0.234)$ & $(0.256)$ \\
\hline Observations & 3,640 & 3,640 & 3,640 & 3,498 & 1,526 & 1,486 & 1,486 & 1,486 \\
\hline $\mathrm{R}$-squared & 0.139 & 0.150 & 0.173 & 0.203 & 0.202 & 0.201 & 0.273 & 0.273 \\
\hline
\end{tabular}

Standard errors in parentheses $* * * \mathrm{p}<0.01, * * \mathrm{p}<0.05, * \mathrm{p}<0.1$

\subsection{Heterogeneity analysis}

To better analyze the gender differences of education intergenerational transmission, we select female migrant workers and male migrant workers for analysis. As shown in Table 5, model (2) shows the female migrant workers sample as the dependent variable for regression analysis, with the results also being significant at the $1 \%$ level, model (3) shows the male migrant workers sample as the dependent variable for regression analysis, with the results also being significant at the $1 \%$ level. To summarize, in terms of education intergenerational transmission, male migrant workers and female migrant workers 
are significantly influenced by the father's education, but this is more obvious for male migrant workers than female migrant workers, which is basically consistent with the traditional Chinese concept of men and women, and also in line with the actual situation of migrant workers. But the overall difference is not very big, which is fully consistent with our current society's increasing emphasis on equal opportunities for men and women.

Table 5: Analysis results of heterogeneity of educational intergenerational transmission

\begin{tabular}{|c|c|c|}
\hline \multirow[t]{2}{*}{ VARIABLES } & $\begin{array}{c}\text { Women } \\
\text { (1) }\end{array}$ & $\begin{array}{c}\text { Man } \\
(2)\end{array}$ \\
\hline & edu & edu \\
\hline \multirow[t]{2}{*}{ edu_f } & $0.149 * * *$ & $0.152 * * *$ \\
\hline & $(0.0281)$ & $(0.0236)$ \\
\hline \multirow[t]{2}{*}{ mar } & $-0.867 * * *$ & -0.241 \\
\hline & $(0.323)$ & $(0.229)$ \\
\hline \multirow[t]{2}{*}{ par } & $1.969 * * *$ & $1.139 * * *$ \\
\hline & $(0.571)$ & $(0.329)$ \\
\hline \multirow[t]{2}{*}{ time } & $-0.0778 * * *$ & $-0.0512 * * *$ \\
\hline & $(0.0117)$ & $(0.00846)$ \\
\hline \multirow[t]{2}{*}{ soci } & -0.00207 & -0.00127 \\
\hline & $(0.00448)$ & $(0.00258)$ \\
\hline \multirow[t]{2}{*}{ qua } & $2.797 * * *$ & $1.640 * * *$ \\
\hline & $(0.293)$ & $(0.204)$ \\
\hline \multirow[t]{2}{*}{ health } & 0.0726 & 0.0738 \\
\hline & $(0.211)$ & $(0.184)$ \\
\hline \multirow[t]{2}{*}{ Constant } & $9.868 * * *$ & $9.250 * * *$ \\
\hline & $(0.418)$ & $(0.342)$ \\
\hline Observations & 665 & 840 \\
\hline $\mathrm{R}$-squared & 0.321 & 0.244 \\
\hline
\end{tabular}

\section{5、 Research Conclusions and Policy}

\section{Recommendations}

This paper analyzes the influence of the father's education level on the education of migrant workers' children from both theoretical and empirical aspects. Through empirical analysis, we can verify the theoretical hypothesis and draw the following two conclusions. First, the education intergenerational transmission effect also exists in the huge labor group of migrant workers, and the father's education level significantly affects the education status of their children's migrant workers. Second, the education intergenerational transmission of migrant workers shows subtle gender differences. Therefore, we should pay special attention to the transmission of this kind of education, as well as a series of influences brought about by this kind of education transmission.

To further play the role of migrant workers in the overall labor market, and to improve the quality of life and happiness of migrant workers, we need to pay more attention to their education investment, and 
we need to strengthen education investment from the perspective of parents, because this investment will produce an intergenerational transfer effect. Therefore, the author thinks it can be improved in the following ways.

First, we should pay more attention to and invest in academic education for migrant workers. According to the conclusion of education intergenerational transfer, the education investment capital of migrant workers affects this generation and even later generations. Therefore, special attention and support should be given to the educational opportunities of migrant workers and their children.

Second, we should strengthen the continuing education of migrant workers and construct an lifelong education mechanism. The current reality is migrant workers generally have low academic qualifications, so in view of the importance of education and intergenerational transmission; we need to solve this problem as quickly as possible. Thus, we should strengthen the continuing education and lifelong education measures of migrant workers.

Third, we should improve the education and training network system for migrant workers. Due to the characteristics of the migrant workers themselves, their job mobility is particularly high, so it is essential to improve their education and training. We need an efficient network system to continue, recognize and guarantee the education of migrant workers, allowing this education to continue to play its role in their lives.

Although this study is aimed at the migration of migrant workers across provinces in China, it has the

\section{Reference:}

[1]]Shao Yihang, Zhang Chaoyang. Relationship between social capital and intergenerational occupational mobility, Economic perspectives, pp. 37-49, Volume 6, 2016.

[2]Ji T. Aggregate Implications of Occupational Inheritance in China and India, SSRN Electronic Journal, pp. 1-43 Volume 12,2014.

[3] Guo Congbin, Ding Xiaohao. 2005. Intergenerational effects of industries and the role of same reference significance for the migrants of various countries. Limited to the availability of intergenerational data, it needs to be further improved. The follow-up research will further collect the data related to the father generation, and discuss the characteristics and rules of occupational mobility of migrant workers' children in more detail.

(Fund Project: This paper is a phased research result of the Ministry of education's humanities and Social Sciences Research Program "Research on the effect of human capital intergenerational transfer and migrant workers' occupational mobility",20YJC840009)

(Note: LI Zhong-bin, corresponding author, professor and doctoral supervisor of Fujian agriculture and Forestry University.)

\section{(Contribution of individual authors to the creation of a scientific article}

DU Xing-yan is responsible for literature review, data analysis and article writing;

LI Zhong-bin is responsible for the guidance and conclusion of the paper)

education in China's labor market segmentation, Educational Research, pp.34-40 Volume 1, 2014.

[4]Hertz T, Jayasundera T, Piraino $P$, et al. The Inheritance of Educational Inequality: International Comparisons and Fifty-Year Trends, The BE Journal of Economic Analysis \& Policy, pp. 1-48, Volume 7, 2008. [5]Van Doorn M, Pop I, Wolbers M H J. Intergenerational transmission of education across European countries and cohorts, European Societies, pp. 93-117, Volume 13, 2011. 
[6]Fessler P , Mooslechner P , Martin Schürz. Intergenerational transmission of educational attainment in Austria,, Empirica, pp. 65-86, Volume 39, 2012.

[7] Ma Xing. Ethnic differences in the intergenerational flow of Education, Journal of Central South University for nationalities, pp. 122.127, Volume 5, 2014.

[8] Sun Yongqiang, Yan Yan. Research on the differences between urban and rural areas in intergenerational transmission of education in China, Journal of Beijing Normal University, pp. 59-67, Volume 6, 2015.

[9] Zhao Hongxia, Gao Yongchao. Comparative study on intergenerational mobility and regional differences of education in China, China Youth Studies, pp. 54-58, Volume 8, 2016.

[10] Wei Xiaoyan. Empirical Study on intergenerational transmission of higher education and its influencing factors, China economic issues, 2017 (6): $87-97$

[11]Zhu Jian, Xu Lei, Wang Hui. Research on the urban-rural differences of education intergenerational transmission, Education and economy, pp. 45-55, Volume 12, 2018.

[12]Li Xiaofei. Urban rural differences and their evolution in the intergenerational transmission of higher education from "Phoenix man" to "second generation of students" and its evolution, Modern university education, pp. 98-103, Volume 1, 2019.

[13] Du Fenglian, Shi Jing, Zhang Yueping, Zhang Lin. is there a father like a son? An analysis of the scale and influencing factors of intergenerational transmission of education in China, Labor economy research, pp.32-51, Volume 7, 2019.

[14] Psacharopoulos G, Patrinos H A. Returns to investment in education: a further update, Education economics, pp. 111-134, Volume 12, 2004.

[15] Deng Feng, Ding Xiaohao. Analysis of the long-term trend of China's return on Education, Statistical research, pp. 39-47, Volume 30, 2013.

[16] Wang Jing, Wu shunchen. Occupational differences in the rate of return on education and the occupational mobility of the new generation of migrant workers, Education \& Economy, pp. 61-68, Volume 6,
2015.

[17]Mccollum D, Liu Y, Findlay A, et al. Determinants of occupational mobility: the importance of place of work, Regional Studies, pp. 1-12, Volume 53, 2018.

[18]Antonio Caparrós Ruiz. Intergenerational occupational dynamics before and during the recent crisis in Spain, Empirica, pp. 1-27, Volume 45, 2018.

[19]Cortes G M, Gallipoli G. The Costs of Occupational Mobility: An Aggregate Analysis, Journal of the European Economic Association, pp. 275-315, Volume 16, 2018.

[20]Kalleberg A L, Mouw T. Occupations, Organizations, and Intragenerational Career Mobility, Review of Sociology, pp. 283-303, Volume 44, 2018.

[21]Wang X , Sun J , Liu X , et al. Psychological contract's effect on job mobility: Evidence from Chinese construction worker, Ekonomska Istraivanja / Economic Research, pp. 1476-1497, Volume 32, 2019. [22]Tran V C , Lee J , Huang T J . Revisiting the Asian second-generation advantage, Ethnic \& Racial Studies, pp.1-22, 2019.

[23]Shin Y, Yuen C. Occupational Mobility and Lifetime Earnings, Canadian Parliamentary Review, pp.231-244, Volume 101, 2019.

[24]Perez S. Intergenerational Occupational Mobility across Three Continents, The Journal of Economic History, pp. 383-416, Volume 79, 2019.

[25]Fedorets A. Changes in Occupational Tasks and Their Association with Individual Wages and Occupational Mobility, German Economic Review, pp. E295-E328, Volume 20, 2019.

[26]Hall M, Greenman E, Yi Y, et al. Job Mobility among Unauthorized Immigrant Workers, Social Forces, pp. 999-1028, Volume 97, 2019.

[27]Lim K , Crane M F , Kansakar D . Examining the role of constrained occupational mobility in the experience of entrapment cognitions, Australian Psychologist, pp.502-512, Volume 54, 2019.

[28] Ming Juan. An empirical analysis of the impact of job transfer on the employment quality of migrant workers, Journal of Hunan Agricultural University (Social Sciences), pp. 38-45, Volume 18, 2018.

\section{Creative Commons Attribution License 4.0 (Attribution 4.0 International, CC BY 4.0)}

This article is published under the terms of the Creative Commons Attribution License 4.0

https://creativecommons.org/licenses/by/4.0/deed.en_US 